\title{
Laparoscopic versus medical treatment of undisturbed ectopic pregnancy, Minia University Hospital
}

\author{
Original \\ Article \\ Khaled Gomaa Mohamad \\ Department of Obstetrics and Gynecology, Faculty of Medicine, Minia University, Minia, \\ Egypt
}

\begin{abstract}
Introduction: The incidence of ectopic pregnancy (EP) increased almost up to a level of $2 \%$ in developed countries. Using of transvaginal ultrasonography and sensitive plasma-human chorionic gonadotropin ( $\beta$-HCG) has enabled an early diagnosis before rupture. Early diagnosis allows the full range of treatment options. So, emergency surgery has been changed to a more benign condition. Administration of methotrexate (MTX) has an acceptance in selected patients and is considered costly effective with no need for waiting period before attempting another pregnancy. Although methotrexate is a teratogenic agent, its half-life is very short.

Aim of work: To evaluate the safety and efficacy of laparoscope versus MTX of well-selected cases of undisturbed ectopic pregnancy.

Materials and Methods: This is a prospective study in Minia University Hospitals during the period from March 2015 to March 2016. Forty patients of undisturbed EPs were divided randomly into two groups (20 for each group), the first group included women undergoing laparoscopic salpingostomy and the second group included women undergoing MTX. Every participant was subjected to full history taking, general, abdominal and vaginal examinations, as well as $\beta$-HCG, abdominal and vaginal ultrasound scan investigations. Only with MTX group and according to Lipscomb 2012, MTX was administrated and assessed. After full range of treatment, a close weekly follow-up of all groups was done by $\beta$-HCG level as well as abdominal and vaginal examination and ultrasonography.

Results: The mean pre-therapeutic level of $\beta$-HCG was $1081.9 \pm 655.85 \mathrm{mIU} / \mathrm{ml}$ in MTX group and $2180.75 \pm 1693.51$ $\mathrm{mIU} / \mathrm{ml}$ in laparoscopy group. As regarding the success rate, MTX group was $70 \%$ and not significantly different from laparoscopic $85 \%$.

Conclusion: Undisturbed EP can be treated effectively by MTX, especially in selected cases depending mainly on $\beta$-HCG low levels pre-therapeutic and follow-up.
\end{abstract}

Key Words: $\beta$-HCG and laparoscope, ectopic pregnancy, methotrexate

Received:7 June 2018, Accepted: 25 June 2018

Corresponding Author: Khaled Gomaa, Department of Obstetrics \& Gynecology, Minia University, Minia, Egypt, Tel.: 01066706698, E-mail: dockhaled5@gmail.com

ISSN: 2090-7265, August 2018, Vol.8, No. 3

\section{INTRODUCTION}

Extra uterine pregnancy can often be diagnosed before the patient's condition is deteriorated, so changed into a more benign condition. Diagnostic integrating transvaginal ultrasound and level of human chorionic gonadotrophin (hCG) measurement are the cornerstone of a timely diagnosis (Ankum et al., 1996). Timely diagnosis allows us to consider the full range of treatment options. This is important not only in focused on immediate therapeutic management success (i.e. elimination of the EP) which is a narrow aim but also retaining optimal fertility for those women desiring future pregnancy (Hajenius et al., 2007).

Nowdays, treatment options for EP patients are surgery, medical treatment or expectant management. In surgery, laparoscopy is now the accepted approach for making salpingostomy or salpingectomy. Administration of MTX has gained an acceptance in selected patients. Expectant management has been advocated based on the knowledge that the course of many early EP is a selflimiting process, ultimately resulting in tubal abortion or re-absorption. A well-recognized hazard after surgical line, systemic MTX treatment and expectant management is persistent trophoblast, abortion or re-absorption. Persistent trophoblast may lead to recurrence of clinical symptoms and is an indication for additional treatment. Serum $\beta$-HCG monitoring enables the timely detection of inadequately declining serum $\beta$-HCG concentrations after treatment (Hajenius et al.,2007) .

At the end, both randomized trial and prospective study found that the cost effectiveness of methotrexate treatment for women was quite substantial (Graczykowski JW and Mishell DR., 1997). 


\section{AIM OF WORK}

To evaluate the safety and efficacy of laparoscopic versus medical management of well selected cases of undisturbed ectopic pregnancy.

\section{PATIENTS AND METHODS}

Study design: Prospective study.

Place and duration of study: Minia University Hospitals during the period from March 2015 to March 2016.

Ethical Approval: The ethical committee of the Department of Obstetrics and Gynaecology at Minia College of Medicine approved the study on $3^{\text {rd }}$ January 2015.

Consent: All participants had signed a written informed consent after they have been made aware of the purpose of the study, interventions, outcome and possible complications. The researcher confirmed confidentiality of their information that will never be used for purposes other than scientific research.

Study sample: Forty patients of undisturbed EPs and after counseling, the women were randomized and divided into two groups ( 20 for each group), the first group (women undergoing to laparoscopic salpingostomy) and the second group (undergoing to MTX).

Study methods: All studied patients were subjected to full history taking including complete medical and surgical history, general examination (pulse, temperature, blood pressure, weight and height). Abdominal and vaginal examinations, investigations $(\beta-\mathrm{hCG}$, serum creatinine, liver function, $\mathrm{Rh}$, and $\mathrm{CBC}$ ). Ultrasound Scan (abdominal and vaginal) was also performed. Lastly and after full range of treatment, a close follow-up mainly by serum $\beta$-hCG level weekly, vital signs, abdominal and vaginal examination in addition to ultrasonography.

MTX administration and assessment: Only with MTX group and according to Lipscomb 2012, day (0) obtained $\beta$-HCG level and sonar, day (1) obtained levels of the $\beta$-HCG, liver function, blood urea, and creatinine as well as administration of a single-dose of MTX $1 \mathrm{mg} /$ kg IM. Day (4) obtained $\beta$-HCG level (baseline level against which subsequent levels are measured). Day (7) obtained $\beta$-HCG and AST levels and perform a complete blood count. Successful treatment: If the $\beta-H C G$ level has dropped $15 \%$ or more at day 7 , obtains weekly $\beta$-HCG levels until they have reached the negative level, if failure occurs, surgical intervention was performed.

Participants (MTX group): Inclusion criteria according to Lipscomb 2012, the patient must be hemodynamically stable, reliable, compliant, and able to return for follow-up care. The size of the gestation should not exceed $4 \mathrm{~cm}$ at its greatest dimension. No evidence of tubal rupture or fetal cardiac activity (by ultrasonographic findings). The $\beta-\mathrm{HCG}$ level is less than $5000 \mathrm{mIU} / \mathrm{Ml}$. The exclusion criteria include coexistent viable intrauterine pregnancy, renal, hepatic or haematological impairment, breast feeding or known hypersensitivity to methotrexate, immunodeficiency/ concurrent use of corticosteroids.

Outcome measures: $\beta-\mathrm{HCG}$ titre on day 4,7 and weekly until it reached zero and HSG after 8 weeks.

Data management: The collected data were analyzed by using the statistical package for social sciences software (SPSS- version19). Graphics were done by Excel Microsoft office 2010. Quantitative data were presented as means and standard deviations, while qualitative data were presented as frequency distribution and percentages. Standard t-tests or the MannWhitney $U$ tests will be used for comparison between patients received systemic MTX and laparoscopy. The probability of less than 0.05 was used as a cut off point for all significant tests.

\section{RESULTS}

Forty patients of undisturbed ectopic pregnancy were divided into two groups, twenty cases received single dose of methotrexate $(1 \mathrm{mg} / \mathrm{kg} \mathrm{im})$ and the remaining cases underwent laparoscopic salpingostomy.

Table 1 : Distribution of the studied patients regarding their descriptive criteria

\begin{tabular}{lccc}
\hline $\begin{array}{l}\text { Descriptive } \\
\text { criteria }\end{array}$ & $\begin{array}{c}\text { Medical } \\
\text { Group } \\
(\mathrm{n}=20)\end{array}$ & $\begin{array}{c}\text { Laparoscopy } \\
\text { Group } \\
(\mathrm{n}=20)\end{array}$ & P. value \\
\hline Age & $18-33$ & $19-36$ & 0.356 \\
$\begin{array}{l}\text { Range } \\
\text { Mean } \pm \text { SD }\end{array}$ & $25.45 \pm 4.01$ & $26.9 \pm 5.67$ & \\
BMI & & & \\
Range & $20-25$ & $18.5-25$ & 0.246 \\
Mean \pm SD & $22.6 \pm 1.46$ & $21.92 \pm 2.1$ & \\
\hline
\end{tabular}

Table 2: Distribution of the studied patients regarding their pretherapeutic B-HCG titre and adnexal mass by ultrasound finding

\begin{tabular}{lcc}
\hline Pre-therapeutic & Range & \\
$\beta$ - HCG & Mean \pm SD & P. value \\
titre (MIU/ML) & & \\
\hline \multirow{2}{*}{ MTX } & $311-2853$ & \\
& $1081.9 \pm 655.85$ & $0.006^{*}$ \\
Laparoscope & $574-6534$ & \\
& $2180.75 \pm 1693.51$ & \\
\hline
\end{tabular}

The mean pre-therapeutic $\beta$ - HCG titre $(\mathrm{miu} / \mathrm{ml})$ of methotrexate group was (1081.9) and of laparoscopic group was (2180.75) and $p$. value was $0.006 *$ 
Table 3: Distribution of the studied patients regarding the result after treatment

\begin{tabular}{lccc}
\hline Result & $\begin{array}{c}\text { MTX group } \\
(\mathrm{n}=20)\end{array}$ & $\begin{array}{c}\text { Laparoscopy } \\
\text { group }(\mathrm{n}=20)\end{array}$ & p.value \\
\hline Failed & $6(30 \%)$ & $3(15 \%)$ & 0.256 \\
Success & $14(70 \%)$ & $17(85 \%)$ & \\
\hline
\end{tabular}

This table shows that success rate of laparoscopy group was $(85 \%)$ and of methotrexate group was $(70 \%)$ and $p$.value was 0.256

\section{DISCUSSION}

Medical treatment by MTX in an outpatient setting is now a realistic option. This modality was introduced in 1991 by Stovall et al. (Stovall TG et al., 1992). In 1997, the first randomized clinical trial on MTX against laparoscopic salpingostomy was published (Hajenius PJ et al., 2000).

In our study, there were no significant differences between the two groups in the baseline characteristics (Table 1).

The parameter considered most important for MTX treatment of unruptured EP is $\beta$ - HCG. (Lipscomb et al., 1999) demonstrated its importance (Lipscomb et al., 1999) and shown that the higher the level of $\beta$ - HCG, the lower the chances of successful treatment. Farquhar CM 2005 was compared with a single dose MTX $(50 \mathrm{mg} / \mathrm{m} 2)$ versus laparoscopic surgery and reported that one single dose of systemic methotrexate intramuscularly ( $50 \mathrm{mg} / \mathrm{m} 2$ or $1 \mathrm{mg} / \mathrm{kg}$ body weight) was significantly less successful than laparoscopic salpingostomy in the elimination of tubal ectopic pregnancy (OR $0.38,95 \%$ CI 0.20 to 0.71 ). This was mainly the result from inadequately declining serum $\beta$-HCG concentrations for which additional methotrexate injections were given (OR 3.3, 95\% CI 1.7 to 6.7$)$. The difference in results as serum $\beta$-HCG was less than $10000 \mathrm{IU} / 1$, but in our study (Table 2) the mean pre-therapeutic level of $\beta-\mathrm{HCG}$ was $1081.9 \pm 655.85 \mathrm{mIU} / \mathrm{ml}$ in MTX group and $2180.75 \pm 1693.51 \mathrm{mIU} / \mathrm{ml}$ in laparoscopy group. Erdem M et al., 2004 reported that the mean pre-treatment $\beta$-HCG level was significantly lower in patients who were successfully treated with MTX than in patients who failed MTX therapy (1,932 \pm $2,361 \mathrm{mIU} / \mathrm{ml}$ vs. $6,955 \pm 2,690 \mathrm{mIU} / \mathrm{ml}$ ) respectively $(p<0.05)$.

As regards the success rate (Table 3), MTX group was $70 \%$ (14/20 patients) and not significantly different from that in the laparoscopic surgery $85 \%$ (17/20 patients) which are near to Krag et al., 2009 who compared a single dose of MTX with laparoscopic surgery and found that the success rate following MTX group was 74\% (39/53 patients) and was not significantly different from that in the laparoscopic surgery 87\% (46/53 patients). Erdem M et al., 2004 reported twenty-two patients $73.3 \%$ were effectively treated with a single-dose of MTX.

DEMETER multicenter trial, medical treatment was compared with conservative surgery in 207 women, and the reported success rate for MTX in 110 patients was 75\% (Fernandez H, et al., 2013), also Van Mello NM et al., 2013 examined 73 women of whom 41 were allocated to single-dose MTX treatment. The primary treatment success rate of onedose MTX was (31/41) 76\%. In nine females (22\%), another MTX treatment was needed. One woman (2\%) underwent surgery.

Moreover, Berretta R et al., 2015 reported that systemic MTX was $86.2 \%$ (56 out of 65 ) and Mostfa et al. 2010 reported that in their study on 72 women diagnosed as un-ruptured tubal ectopic pregnancy. Systemic treatment with a single dose methotrexate $(50 \mathrm{mg} / \mathrm{m} 2$ intramuscularly) was used for 32 women and 40 cases underwent surgery. The primary treatment with a single dose intramuscular MTX was success in 28 cases $87.5 \%$ of the situations. In the failed 4 cases $(12.5 \%)$, a second single dose intramuscular MTX treatment was offered. Treatment was failed only in two cases and managed by salpingectomy. Sagiv $\mathrm{R}$ et al., 2012 recorded that of 20 cases treated by laparoscopy, 19 cases (95\%) were successfully performed without any additional intervention and one case was needed to salpingectomy during the initial surgery.

The reported success rates of MTX therapy range from $63 \%$ to $96.7 \%$. The heterogeneity of these results is due to variations in patient characteristics, in study inclusion criteria as pretreatment $\beta$ - HCG level, methotrexate treatment protocols and the different definitions of treatment failure. Some studies, for example, considered treatment failures to be only cases that finally required surgery (Fernandez $\mathrm{H}$, et al., 1998) (Hajenius PJ et al., 2000) (Fernandez H, et al., 2013)

In spite of all these results, Hajenius PJ et al., 2000 found that MTX in a single dose intramuscular was not effective enough in eliminating the tubal pregnancy vs laparoscopic salpingostomy, this is as a result of inadequately decreasing in HCG concentrations after one single dose of methotrexate necessitating additional methotrexate injections or surgical interventions. Methotrexate injection results a costs savings in compared with laparoscopic 
salpingostomy, only in women with low initial serum HCG concentrations.

\section{ACKNOWLEDGMENT}

The author would like to thank all participants and the persons who helped us in conduction of the research.

\section{CONFLICT OF INTEREST}

There are no conflicts of interest

\section{REFERENCES}

1. Ankum WM, Mol BWJ, Van der Veen $F$ and Bossuyt PMM (1996): Risk factors for ectopic pregnancy: A meta-analysis. Fertil Steril. 65: 1093-1099.

2. Berretta R1, Dall'Asta A, Merisio C, Monica M, Lori L, Galli L, Mautone D, and Frusca T. (2015): Tubal ectopic pregnancy our experience from 2000 to 2013. Acta Biomed. Sep 14;86(2):176-80.

3. de Bennetot M, Rabischong B, Aublet-Cuvelier B, Belard F, Fernandez H, Bouyer J, Canis M and Pouly JL. (2012): Fertility after tubal ectopic pregnancy: results of a population-based study. Fertil Steril. Nov; 98(5):1271-6.

4. Erdem M1, Erdem A, Arslan M, Oç A, Biberoğlu K and Gürsoy R. (2004): Single-dose methotrexate for the treatment of unruptured ectopic pregnancy. Dec;270(4):201-4.

5. Farquhar CM. (2005): Ectopic pregnancy. Lancet, Aug 13-19. 366 (9485): 583-91.

6. Fernandez H and Bourget P. (1993): Rising beta-hCG titres following laparoscopic injection of methotrexate into unruptured, viable tubal pregnancies. Br J Obstet Gynaecol. Dec;100(12):1153.

7. Fernandez H, Yves Vincent SC, Pauthier S, Audibert F and Frydman R. Randomized (1998): Trial of conservative laparoscopic treatment and methotrexate administration in ectopic pregnancy and subsequent fertility. Hum Reprod. Nov;13(11):3239-43.

8. Fernandez H1, Capmas P, Lucot JP, Resch B, Panel $\mathrm{P}$ and Bouyer J; GROG. (2013): Fertility after ectopic pregnancy: the DEMETER randomized trial. Hum Reprod. 2013 May;28(5):1247-53.
9. Graczykowski JW, Mishell DR Jr (2002): Methotrexate prophylaxis for persistent ectopic pregnancy after conservative treatment by salpingostomy. Obstet Gynecol 2002; 89: 118- 122

10. Hajenius PJ, Engelsbel S, MOL BWJ, Vander Veca F, Ankum WM, Bossuyt POM M (2000): Randomized trial of Systemic MTX. Versus Laparoscopic Salpingostomy in Patients with tubal Pregnancy. Lancet, 350; 774-9.

11. Hajenius PJ, Mol F, Mol BW, Bossuyt PM, Ankum WM and van der Veen F. (2007): Interventions for tubal ectopic pregnancy. Cochrane Database Syst Rev. Jan 24. CD000324.

12. Krag Moeller LB1, Moeller C, Thomsen SG, Andersen LF, Lundvall L, Lidegaard, Kjer JJ, Ingemanssen JL, Zobbe V, Floridon C, Petersen J and Ottesen B. (2009): Success and spontaneous pregnancy rates following systemic methotrexate versus laparoscopic surgery for tubal pregnancies: a randomized trial. Acta Obstet Gynecol Scand. 88(12):1331-7.

13. Lipscomb G H, Puckett K J, Bran D and Ling F W. (1999): Management of separation pain after single-dose methotrexate therapy for ectopic pregnancy. Obstet Gynecol, 3: 590-3.

14. Moustafa H, Rizk B, Brooks N, Steffler B, Baker S and Puscheck E. (2010): Cervical pregnancy. In: Rizk B, editor. Ultrasound in reproduc- tive medicine and infertility. Cambridge: Cambridge University Press; p. 276-82 [chapter 33].

15. Sagiv R, Debby A, Feit H, Cohen-Sacher B, Keidar $\mathrm{R}$ and Golan A.(2012 ): The opti $\neg$ mal cutoff serum level of human chorionic gonadotropin for efficacy of methotrexate treatment in women with extrauterine pregnancy. Int $\mathrm{J}$ Gynaecol Obstet. 116(2):101-104

16. Stovall T, Ling F, Carson S and Buster J, (1992): Serum progesterone and uterine curettage in differential diagnosis of ectopic pregnancy. Fertil. Steril. (Feb.) Vol. 57, No. 2, pp. 456-458.

17. van Mello NM, Mol F and Verhoeve HR. (2013): Methotrexate or expectant management in women with an ectopic pregnancy or pregnancy of unknown location and low serum hCG concentrations? A randomized comparison. Hum Reprod. 28(1):60-67. 